\title{
Introduction to "Tsunami Science: Ten Years After the 2004 Indian Ocean Tsunami. Volume I"
}

\author{
Alexander B. Rabinovich, ${ }^{1,2}$ Eric L. Geist ${ }^{3}$ Hermann M. Fritz, ${ }^{4}$ and Jose C. Borrero 5,6
}

\begin{abstract}
Twenty-two papers on the study of tsunamis are included in Volume I of the PAGEOPH topical issue "Tsunami Science: Ten Years after the 2004 Indian Ocean Tsunami." Eight papers examine various aspects of past events with an emphasis on case and regional studies. Five papers are on tsunami warning and forecast, including the improvement of existing tsunami warning systems and the development of new warning systems in the northeast Atlantic and Mediterranean region. Three more papers present the results of analytical studies and discuss benchmark problems. Four papers report the impacts of tsunamis, including the detailed calculation of inundation onshore and into rivers and probabilistic analysis for engineering purposes. The final two papers relate to important investigations of the source and tsunami generation. Overall, the volume not only addresses the pivotal 2004 Indian Ocean (Sumatra) and 2011 Japan (Tohoku) tsunamis, but also examines the tsunami hazard posed to other critical coasts in the world.
\end{abstract}

Key words: Tsunami investigation, 2004 Indian Ocean earthquake and tsunami, 2011 Tohoku earthquake and tsunami, source parameters, Pacific Ocean, DART, tsunami warning system, tsunami records, tsunami modelling, spectral analysis.

\section{Introduction}

The Indian Ocean (Sumatra) tsunami of 26 December 2004 was one of the world's most destructive

1 Department of Fisheries and Oceans, Institute of Ocean Sciences, 9860 West Saanich Rd., Sidney, BC V8L 4B2, Canada. E-mail: Alexander.Rabinovich@dfo-mpo.gc.ca; A.B.Rabinovich@gmail.com

2 P.P. Shirshov Institute of Oceanology, Russian Academy of Sciences, 36 Nakhimovsky Pr., Moscow 117997, Russia.

3 US Geological Survey, 345 Middlefield Rd., MS 999, Menlo Park, CA 94025, USA. E-mail: egeist@usgs.gov

4 School of Civil and Environmental Engineering, Georgia Institute of Technology, Atlanta, GA 30332, USA. E-mail: fritz@gatech.edu

5 eCoast Ltd., Box 151, Raglan 3225, New Zealand. E-mail: jborrero@usc.edu; jose@ecoast.co.nz

6 Department of Civil and Environmental Engineering, University of Southern California, Los Angeles, CA, USA. natural disasters. Spawned by a magnitude $\left(M_{\mathrm{w}}\right) 9.1$ earthquake (third strongest ever instrumentally recorded), the "Boxing Day" tsunami killed approximately 230,000 people in 14 countries around the Indian Ocean. Among the victims were citizens of more than 60 countries, many of them on holiday. The tsunami propagated as far as the North Pacific and North Atlantic (RABINOvich et al. 2006) and was probably the most catastrophic and deadliest tsunami in recorded history.

The devastating 2004 tsunami represents a scientific dividing line. Prior to the monumental event, the term "tsunami" was familiar only to specialists. Within hours of the event, the entire world came to understand the power of tsunami waves. Thousands of new researchers from different fields entered tsunami science, bringing their diverse experience along with new ideas. Various countries from around the globe contributed major funding to tsunami research, enabling the installation of hundreds of new highprecision instruments, the development of new technology, and the establishment of more modern communication systems. As a result, incredible progress has been achieved in tsunami research and operation during the ten years after the 2004 Indian Ocean tsunami.

Tsunami warning and hazard mitigation systems have dramatically improved. The tsunami observational network of coastal tide gauges has been significantly reconstructed, upgraded, and expanded. Tsunami waves began to be monitored in both the deep ocean and from space. A large number of Deepocean Assessment and Reporting of Tsunamis (DART) stations have been emplaced in optimized alignment with the subduction zones encircling the entire Pacific Ocean; DARTs are now also deployed in the Indian and Atlantic Oceans. These new, precise instruments have yielded thousands of coastal and 
hundreds of deep-water, high-quality tsunami records, enabling researchers to refute some previous misconceptions and to improve knowledge significantly about tsunami physics. Modern numerical models, combined with open-ocean DART records, make it possible to forecast tsunami waves for coastal sites with reliable accuracy soon after a major earthquake.

However, despite the recent advances, tsunamis remain a major threat to coastal infrastructure and human life. Destructive tsunami events continue to kill people and create enormous damage. Several catastrophic events occurred in 10 years after the 2004 Indian Ocean (Sumatra) tsunami, including the 2006 Java, 2009 Samoa, 2010 Chile, and 2010 Mentawai tsunamis with hundreds of fatalities per event. The Tohoku (Great East Japan) tsunami of 11 March 2011, which killed almost 20,000 people and destroyed the Fukushima Daiichi nuclear power plant, was a tragic example of a chain of devastating events (SATAKE et al. 2013a). We can state with some certainty that the number of victims would have been many times higher without existing tsunami mitigation programs and effective tsunami warning services in Japan and other countries.

The present volume was prepared by the Tsunami Commission that was established within the International Union of Geodesy and Geophysics (IUGG) following the 1960 Chile tsunami. The 1960 tsunami, generated by the largest $\left(M_{\mathrm{w}} 9.5\right)$ instrumentally recorded earthquake, propagated throughout the entire Pacific Ocean, affecting countries located far from the source with 142 fatalities in Japan almost a day later, 61 in Hawaii, and 32 in the Philippines (IGARASHI et al. 2011). It became obvious that tsunami investigation and effective tsunami warning is impossible without intensive international cooperation. Since 1960, the Tsunami Commission has held biannual International Tsunami Symposia and published special volumes of selected papers. Several such volumes have been published during the 10 years following the 2004 Sumatra tsunami, including SAtAKe et al. (2007, 2011a, b, 2013a, b) and Cummins et al. (2008, 2009). From this point of view, these volumes can be considered the frontiers of tsunami science and research, as well as a record of continuous progress in tsunami warning and hazard mitigation. Two recent catastrophic tsunamis, the
2010 Chile and 2011 Tohoku, as well as other events that occurred in 2011 and 2012, attracted much attention and revealed significant new information and data, which were published in an extra, inter-session volume (RABINOVICH et al. 2014).

This volume is mainly based on papers presented at the 26th International Tsunami Symposium that was held from 25 to 28 September 2013 in Göcek, Turkey and Rhodes, Greece. Altogether, the symposium comprised about 150 presentations. For the first time in history, two countries hosted the tsunami symposium. Also for the first time, two tsunami sessions, one mainly focusing on the tsunami physics and the other focusing on paleotsunami studies, were convened in parallel. At the business meeting of the Tsunami Commission, it was decided to publish selected papers presented at this symposium, as well as other papers on related topics. Volume I comprises the first half contributing 22 papers, which became ready for publication by December 2014. Approximately the same number of papers will be published forthcoming in Volume II.

\section{Case Studies}

Case studies are an important part of tsunami research that highlight the hazard for specific areasoften areas that have been overlooked for tsunamis. For example, Heidarzadeh and SATAKe (2015) re-evaluate the source for the 1945 Makran tsunami that struck Oman, Iran, Pakistan, and India. They find that earthquake rupture needs to extend into deep water to explain the tsunami observations. Also from the Indian Ocean, NeNTwig et al. (2015) study sedimentary deposits left by the 2004 Indian Ocean tsunami in the Seychelles Islands and find that tsunami sediments caused a change of habitat in mangrove forests on the Islands. In the South Pacific Ocean, the great 2007 Solomon Islands earthquake ruptured across a triple junction leaving behind significant bio- and geomarkers of crust rupture and generated tsunami waves. WeI et al. (2015) developed tsunami inundation models for the Solomon Islands, highlighting the accuracy and efficiency of the tsunameter-derived tsunami source for near-field tsunami impact assessments along a complex archipelago. MuROTANi et al. 
(2015) examined forerunner tsunami waves generated immediately after the 2011 Tohoku-Oki earthquake in the Sea of Japan; they found that these waves, recorded both on the west coast of Japan and on Primorye coast of Russia, were caused by the horizontal displacement of the seafloor slope.

The 2012 Haida Gwaii earthquake was the second strongest instrumentally recorded earthquake in Canadian history and generated a sizable tsunami. FINE et al. (2015) use observations of this event, including those from Canada's deep-ocean cabled observatory, to formulate a detailed source model for this event. The initial model results were used to specify sites of particular interest for post-tsunami field surveys on the coast of Moresby Island (Haida Gwaii), while the field survey observations (LEONARD and BEDNARSKI 2014) were used, in turn, to verify the numerical simulations. Deep-ocean measurements are also critical to the study by HeidARZADEH et al. (2015) who examine delays in the observed 2014 Chile tsunami compared to what was predicted. BorRero et al. (2015) systematically examine the tsunami hazard at New Zealand ports from Pacific Rim earthquakes and find that earthquakes off Central America present the largest hazard. Also, Borrero and Goring (2015) specifically examine the tsunamis originating from South American subduction zones, focusing on one harbor (Lyttelton, South Island) in New Zealand.

\section{Forecast/Warning Studies}

Numerical models that provide real-time forecasting of tsunami amplitudes have been developed, starting even before the 2004 Indian Ocean event. Gica et al. (2015) examine the sensitivity that different types of data collected in real time have on the accuracy of tsunami forecasts and find, intuitively, that direct observations of tsunami waveforms have the biggest impact. In the first of two companion papers, Clement and Reymond (2015) describe new tools to determine the seismic moment and focal mechanism of tsunamigenic earthquakes and to identify anomalous "tsunami earthquakes" for warning systems. In the second paper, JAMELOT and REYMOND (2015) present two numerical tsunami modelling tools to forecast runup, inundation and flow velocities in French Polynesia. Schindele et al. (2015) describe the tools used by the French Tsunami Warning Center as part of the Northeastern Atlantic and Mediterranean tsunami warning system. From both a scientific and an emergency management perspective, CASSIDY (2015) presents an informative comparison of the earthquake that generated the 2004 Indian Ocean event and potential earthquakes and tsunamis along the Cascadia subduction zone.

\section{Benchmark and Analytical Studies}

Given the critical use of numerical tsunami models to determine hazard and evacuation zones, much emphasis has been placed in recent years on benchmarking models against analytical solutions, laboratory experiments and case studies. Whereas most benchmarks relate to amplitude, runup, and inundation, the study by Arcos and LeVeque (2015) benchmarks the GeoClaw model with respect to current velocities, which have only recently become available in the field. More traditional benchmark exercises are presented by HORRILlo et al. (2015) who describe validation of maximum surface amplitude and runup for a number of different tsunami models used to predict inundation for evacuation plans, under the auspices of the U.S. National Tsunami Hazard Mitigation Program. It is important to determine accurately the tsunami response in bays of different configurations. Toward this end, HARRIs et al. (2015) analytically derive the $1 \mathrm{D}$, nonlinear tsunami response in trapezoidal bays and compare the results with those calculated from a $2 \mathrm{D}$ numerical model.

\section{Inundation and Structural Studies}

New developments have been made in the last 10 years in preparing tsunami inundation maps. For example, Dilmen et al. (2015) use very high-resolution, near-shore bathymetry and topography from multispectral satellite imagery to prepare tsunami inundation maps for the region near Fethiye, Turkey. Ozer et al. (2015) describe and calculate the "hydrodynamic demand" parameter in inundation zones that estimates damage to coastal structures from drag 
forces during tsunami runup. Within the last 10 years, probabilistic methods have been developed to assess tsunami hazards for engineering purposes. OMIRA et al. (2015) present a regional probabilistic tsunami hazard assessment for coastlines along the northeast Atlantic Ocean, using in part Bayesian methods to incorporate catalog data. The unique hydrodynamic response of tsunamis as they propagate up into rivers is examined by Tolkova et al. (2015). They find that different rivers for different tsunami events modulate the tsunami in very similar ways.

\section{Source and Generation Studies}

Volume I of "Tsunami Science: Ten Years after the 2004 Indian Ocean Tsunami" wraps up with two papers that provide new examinations on the sources of tsunamis. Hossen et al. (2015) find that Time Reverse Imaging (TRI) used to reconstruct the initial sea-surface displacement for tsunamis obviates many of the assumptions used for traditional, forward modelling of tsunami sources. Stefanakis et al. (2015) examine the effect of uplifting a cylindrical sill during tsunami generation, analogous to the uplift of a seamount. They find that whereas the sill effect reduces wave heights in the far field, there is amplification of wave heights above the sill, owing to partial wave trapping.

\section{Acknowledgments}

We would like to thank Dr. Renata Dmowska, the Editor-in-Chief for Topical Issues of PAGEOPH, for arranging and encouraging us to organize these topical volumes. We also thank Ms. Priyanka Ganesh at Journals Editorial Office of Springer for her timely editorial assistance. Finally, we would like to thank all the authors and reviewers who contributed to these topical volumes.

\section{REFERENCES}

Arcos, M.E.M., LeVeque, R.J. (2015), Validating velocities in the GeoClaw tsunami model using observations near Hawaii from the 2011 Tohoku tsunami. Pure Appl. Geophys., 172 (3-4) (this issue), doi:10.1007/s00024-014-0980-y

Borrero, J.C., Goring, D.G. (2015), South American tsunamis in Lyttelton Harbor, New Zealand. Pure Appl. Geophys., 172 (3-4) (this issue), doi:10.1007/s00024-014-10

Borrero, J.C., Goring, D.G., Greer, S.D., Power, W.L. (2015), Far-field tsunami hazard in New Zealand ports. Pure Appl. Geophys., 172 (3-4) (this issue), doi:10.1007/s00024-0140987-4

CAssidy, J.F. (2015), The 2004 Sumatra earthquake and tsunami: lessons learned in subduction zone science and emergency management for the Cascadia Subduction Zone. Pure Appl. Geophys., 172 (3-4) (this issue), doi:10.1007/s00024-014-10

Clément, J., Reymond, D. (2015), New tsunami forecast tools for the French Polynesia Tsunami Warning System. Part I: moment tensor, slowness and seismic source inversion. Pure Appl. Geophys., 172 (3-4) (this issue), doi:10.1007/s00024-014-0888-6

Cummins, P.R., Kong, L.S.L., SATAKe, K. (2008), Tsunami Science Four Years after the 2004 Indian Ocean Tsunami. Part I: Modelling and Hazard Assessment, Pure Appl. Geophys. 165 (11-12), Topical Issue.

Cummins, P.R., Kong, L.S.L., Satake, K. (2009), Tsunami Science Four Years after the 2004 Indian Ocean Tsunami. Part II: Observation and data Analysis, Pure Appl. Geophys. 166 (1-2), Topical Issue.

Dilmen, D.I., Kemec, S., Yalçiner, A.C., Düzgün, S., Zaytsev, A. (2015), Development of a tsunami inundation map in detecting tsunami risk in Gulf of Fethiye, Turkey. Pure Appl. Geophys., 172 (3-4) (this issue), doi:10.1007/s00024-014-0936-2

Fine, I. V., Cherniawsky, J.Y., Thomson, R.E., Rabinovich, A.B., KRASSOVSKI M.V. (2015), Observations and numerical modeling of the 2012 Haida Gwaii tsunami off the coast of British Columbia. Pure Appl. Geophys., 172 (3-4) (this issue), doi:10. 1007/s00024-014-1012-7

Gica, E., Titov, V.V., Moore, C., Wei, Y. (2015), Tsunami simulation using sources inferred from various measurement data: Implications for the model forecast. Pure Appl. Geophys., 172 (3-4) (this issue), doi:10.1007/s00024-014-0979-4

Jamelot, A., Reymond, D. (2015), New tsunami forecast tools for the French Polynesia Tsunami Warning System. Part II: Numerical modelling and tsunami height estimation. Pure Appl. Geophys., 172 (3-4) (this issue), doi:10.1007/s00024-0140997-2

Harris, M.W., Nicolsky, D.J., Pelinovsky, E.N., Rybkin, A.V. (2015), Runup of nonlinear long waves in trapezoidal bays: 1-D analytical theory and 2-D numerical computations. Pure Appl. Geophys., 172 (3-4) (this issue), doi:10.1007/s00024-014-10

Heidarzadeh, M., Satake, K. (2015), New insights into the source of the Makran tsunami of 27 November 1945 from tsunami waveforms and coastal deformation data. Pure Appl. Geophys., 172 (3-4) (this issue), doi:10.1007/s00024-014-0948-y

Heidarzadeh, M., Satake, K. Murotani, S., Gusman, A.R., Watada, S. (2015), Deep-water characteristics of the transPacific tsunami from the 1 April 2014 Mw 8.2, Iquique, Chile earthquake. Pure Appl. Geophys., 172 (3-4) (this issue), doi:10. 1007/s00024-014-0983-8

Horrillo, J., Grilli, S.T., Nicolsky, D., Volker, R., Zhang, J. (2015), Performance benchmarking tsunami models for NTHMP's inundation mapping activities. Pure Appl. Geophys., 172 (3-4) (this issue), doi:10.1007/s00024-014-0891-y 
Hossen, M. J., Cummins, P.R., Roberts, S.G., Allgeyer, S. (2015), Time reverse imaging of the tsunami source. Pure Appl. Geophys., 172 (3-4) (this issue), doi:10.1007/s00024-014-10.

Igarashi, Y., Kong, L., Yamamoto, M., McCreery, C.S. (2011), Anatomy of historical tsunamis: lessons learned for tsunami warning, Pure Appl. Geophys., 168, 2043-2063; doi:10.1007/ s00024-011-0287-1.

LeOnARD, L.J., Bednarski, J.M. (2014), Field survey following the 27 October 2012 Haida Gwaii tsunami, Pure Appl. Geophys., 171, 3467-3482; doi:10.1007/s00024-014-0792-0

Murotani, S., Iwai, M., Satake, K., Shevchenko, G., Loskutov, A. (2015), Tsunami forerunner of the 2011 Tohoku earthquake observed in the Sea of Japan. Pure Appl. Geophys., 172 (3-4) (this issue), doi:10.1007/s00024-014

Nentwig, V., Bahlburg, H., Monthy, D. (2015), Sedimentology of coastal deposits in the Seychelles Islands-evidence of the Indian Ocean tsunami 2004. Pure Appl. Geophys., 172 (3-4) (this issue), doi:10.1007/s00024-014-0990-9

Omira, R., Baptista, M.A., Matias, L. (2015), Probabilistic tsunami hazard in the Northeast Atlantic from near- and far-field tectonic sources. Pure Appl. Geophys., 172 (3-4) (this issue), doi:10.1007/s00024-014-0949-X

Ozer C.S., Yalçiner, A.C., Zaytsev, A. (2015), Investigation of tsunami hydrodynamic parameters in inundation zone with different structural layout. Pure Appl. Geophys., 172 (3-4) (this issue), doi:10.1007/s00024-014-0947-z

Rabinovich, A.B., Thomson, R.E., Stephenson, F.E. (2006), The Sumatra Tsunami of 26 December 2004 as observed in the North Pacific and North Atlantic Oceans, Surveys Geophys. 27, 647-677.

Rabinovich, A.B., Borrero, J.C., Fritz, H.M. (2014), Tsunamis in the Pacific Ocean: 2010-2011. Pure Appl. Geophys., 171 (12), Topical Issue.
Satake, K., Okal, E.A., Borrero, J.C. (2007), Tsunami and its Hazards in the Indian and Pacific Oceans, Pure Appl. Geophys., 164 (2-3), Topical Issue.

Satake K., Rabinovich, A.B., KânoĞLu, U., Tinti, S. (2011a), Tsunamis in the World Ocean: Past, Present, and Future. Volume I, Pure Appl. Geophys., 168 (6-7), Topical Issue.

Satake K., Rabinovich, A.B., KânoĞLu, U., Tinti, S. (2011b), Tsunamis in the World Ocean: Past, Present, and Future. Volume II, Pure Appl. Geophys., 168 (11), Topical Issue.

Satake K., Rabinovich, A.B., Dominey-Howes, D., Borrero, J.C. (2013a), Historical and Recent Catastrophic Tsunamis in the World: Past, Present, and Future. Volume I: The 2011 Tohoku Tsunami. Pure Appl. Geophys., 170 (6-8), Topical Issue.

Satake K., Rabinovich, A.B., Dominey-Howes, D., Borrero, J.C. (2013b), Historical and Recent Catastrophic Tsunamis in the World: Past, Present, and Future. Volume II: Tsunamis from 1755 to 2010. Pure Appl. Geophys., 170 (9-10), Topical Issue.

Schindelé, F., Gailler, A., Hébert, H., Loevenbruck, A., GutierRez, E., Monnier, A., Roudil, P., Reymond, D., Rivera, L. (2015), Implementation and challenges of the Tsunami Warning System in the Western Mediterranean. Pure Appl. Geophys., 172 (3-4) (this issue), doi:10.1007/s00024-014-0950-4.

Stefanakis, T.S., Dias, F., Synolakis, C. (2015), Tsunami generation above a sill. Pure Appl. Geophys., 172 (3-4) (this issue), doi:10.1007/s00024-014-10

Tolkova, E., Tanaka, H., Roh, M. (2015), Tsunami observations in rivers from a perspective of tsunami interaction with tide and riverine flow. Pure Appl. Geophys. 172 (3-4) (this issue), doi:10. 1007/s00024-014-09-10

Wei, Y., Fritz, H.M., Titov, V.V., Uslu, B., Chamberlin, C., Kalligeris, N. (2015), Source models and near-field impact of the 1 April 2007 Solomon Islands tsunami. Pure Appl. Geophys. 172 (3-4) (this issue), doi:10.1007/s00024-014-09-10 